\title{
PERAN SUPERVISI PENDIDIKAN DALAM MENINGKATKAN MUTU PENDIDIKAN DI INDONESIA
}

\author{
Tia Agustina Nasution \\ tiaagustinanst@gmail.com
}

\begin{abstract}
ABSTRAK
Pendidikan di Indonesia diharapkan dapat menghasilkan generasi penerus bangsa yang produktif, kreatif, inovatif dan afektif serta berprestasi dalam bidang akademik maupun non akademik sehingga dapat bersaing di kancah nasional dan internasional. Diperlukan adanya supervisi pendidikan untuk meningkatkan prestasi belajar siswa dan membentuk karakter siswa sehingga dapat meningkatkan mutu pembelajaran serta mencapai tujuan pendidikan secara nasional. Peningkatan mutu pendidikan harus dilakukan secara berkesinambungan dan dilakukan oleh seluruh elemen yang terlibat dalam proses pembelajaran disekolah termasuk peserta didik, tenaga pendidik, tenaga kependidikan, orang tua serta masyrakat dan lingkungan sekitar. Dengan adanya kerjasama diantara semua elemen tersebut maka mutu pendidikan dapat ditingkatkan sehingga tidak tertinggal dengan perkembangan ilmu dan teknologi yang sangat pesat.
\end{abstract}

Kata kunci: supervisi pendidikan, peningkatkan mutu pendidikan

\section{LATAR BELAKANG}

Kemajuan suatu negara salah satunya dipengaruhi oleh kualitas pendididkan di negara tersebut. Pendidikan merupakan kegiatan belajar mengajar melalui interaksi antara peserta didik, pendidik dan sumber belajar. Mutu pendidikan sangat bergantung kepada ketiga komponen utama tersebut dan selebihnya dipengaruhi oleh masyarakat dan lingkungan sekitar. Untuk menunjang peningkatan mutu pendidikan maka diharapkan setiap tenaga pendidik dan tenaga kependidikan dapat mengetahui pentingnya supervisi pendidikan dalam proses pembelajaran. Sehingga setiap tenaga pendidik dan kependidikan dapat mengimplementasikan peran sebagai supervisor dengan baik sesuai hak dan kewenangannya.Pendidikan diharapkan dapat melahirkan generasi penerus bangsa yang berpontensi akademik maupun non akademik sehingga mampu bersaing secara nasional dan internasional.

Supervisi pendidikan berfungsi untuk mengembalikan dan mengoptimalkan sistem pendidikan di Indonesia. Namun pada pelaksanaannya, supervisi pendidikan masih terdapat beberapa kekurangan seperti supervisior yang belum bisa memaksimalkan tugas tugasnya, kurangnya kesadaran akan pentingnya supervisi pendidikan untuk menciptakan pendidikan yang berkualitas serta minimnya sarana prasarana untuk melaksanakan supervisi pendidikan.Rendahnya kualitas pendidikan di Indonesia membutuhkan pengoptimalan strategi pelaksanaan supervisi pendidikan untuk meningkatkan mutu pendidikan.

Berdasarkan uraian diatas, permasalahan dalam tulisan ini adalah (1) Bagaimana mutu pendidikan di Indonesia ? (2) Bagaimana peran supervisi pendidikan dalam meningkatkan mutu pendidikan di Indonesia? Tujuan tulisan ini adalah untuk mengetahuhi peran supervisi dalam meningkatkan mutu pendidikan di Indonesia.

\section{PEMBAHASAN}

\section{Mutu Pendidikan di Indonesia}

Pengertian mutu pendidikan sebagaimana yang dikemukakan oleh Suti (Suti, 2011)Mutu Pendidikan adalah pengelolaan pendidikan untuk menciptakan keunggulan berupa prestasi akademik maupun non akademik pada peserta didik sehingga peserta didik dapat menyelesaikan kegiatan pembelajaran dengan baik dan lulus pada jenjang pendidikan yang sedang ditempuhnya. Untuk menilai mutu pendidikan diperlukan beberapa pendekatan yaitu perbaikan secara terus-menerus, menentukan standar mutu, perubahan kultur, perubahan organisasidan mempertahankan hubungan dengan pelanggan. 
Komponen yang berpengaruh terhadap peningkatan mutu pendidikan sebagaimana yang dikutip dari Suryana(Suryana, n.d.) meliputi (1) ketersediaan pendidik dan tenaga kependidikan yang belum memadai baik secara kuantitas dan kualitas, maupun kesejahteraannya; (2) prasarana dan sarana belajar yang belum tersedia dan belum didayagunakan secara optimal; (3) pendanaan pendidikan yang belum memadai untuk menunjang mutu pembelajaran; dan (4) proses pembelajaran yang belum efisien dan efektif.

Gambaran prestasi belajar siswa dikutip dari sabandi (Sabandi, 2013) berdasarkan Mulyadi, 2012hasil penilaian yang dilakukan oleh International Association for the Evaluation of Educational Achievement Study Center Boston College tersebut, diikuti 600.000 siswa dari 63 negara terhadap Trends in Mathematics and Science Study (TIMSS); Indonesia diwakili oleh siswa kelas VIII tahun 2011. Hasil penilaian tersebut mengunggapkan bahwa Indonesia dalam bidang Matematika berada di urutan ke skor 386 dari 42 negara yang siswanya dites (skor Indonesia turun 11 angka dari penilaian tahun 2007).

Dari keterangan tersebut dapat dilihat kualitas pendidikan di Indonesia masih rendah terutama dalam bidang matematika padahal Indonesia merupakan negara yang memiliki banyak Sumber Daya Manusia (SDM). Namun SDM tersebut tidak mampu bersaing secara internasional salah satunya disebabkan oleh prestasi yang rendah. Oleh karena itu diperlukan upaya dalam meningkatkan mutu pendidikan di Indonesia salah satunya dengan mengoptimalkan peran supervisi pendidikan. Perlu adanya perbaikan dan pengoptimalan secara berkesinambungan dari komponen-komponen pendidikan untuk mencapai mutu pendidikan yang optimal.

\section{Peran Supervisi Pendidikan dalam Meningkatkan Mutu Pendidikan di Indonesia}

Menurut S. Wajowasito dan W.J.S Poerwadarminta yang dikutip olehDirektorat Tenaga Kependidikan (Pendidikan, 2008) yaitu Supervisi dialih bahasakan dari perkataan inggris "Supervision" artinya pengawasan. Individu yang menjalankan tugas sebagai supervisi pendididikan disebut supervisior. Seorang supervisior harus profesional dan akan lebih baik jika ia memiliki jabatan yang lebih tinggi atau lebih berwibawa diantara tenaga pendidik dan tenaga kependidikan lainnya seperti kepala sekolah.

Supervisi pendidikan berperan untuk mengawasi kegiatan jalannya pendidikan, dan memperbaiki kekekurangan dan kesalahan dalam proses pendididikan untuk meningkatkan mutu pendidikan. Mutu pendidikan dapat dilihat dari prestasi akademik dan non akademik peserta didik dalam kancah nasional dan internasional. Sehingga keberhasilan pelaksanaan supervisipendidikan dapat diukur dari peningkatan prestasi belajar peserta didik. Selain itu sebagaimana yang diungkapkan oleh Rahmat (Rahmat, 2015)supervisi adalah ilmu tentang cara membina sumber daya manusia yang berperan pada pelaksanaan pendidikan yaitu pendidik untuk mencapai tujuan yang telah disepakati dan dijalankan oleh supervisior yaitu pengawas dan kepala sekolah. Supervisior berperan mengawasi, memimpin, membina, mengontrol sumber daya yang meliputi perencanaan, pengamatan, pembinaan dan pengawasan.

Kompetensi-kompetensi yang harus dimiliki oleh supervisor dikutip dari Direktorat Tenaga Pendidikan(Pendidikan, 2008) sebagai berikut : (1). Mampu melakukan supervisi sesuai prosedur dan teknik-teknik yang tepat (2). Mampu melakukan monitoring, evaluasi dan pelaporan program pendidikan sesuai dengan prosedur yang tepat (3). Memahami dan menghayati arti, tujuan dan teknik supervisi (4). Menyusun program supervisi pendidikan (5). Melaksanakan program supervisi pendidikan (6). Memanfaatkan hasil-hasil supervisi (7). Melaksanakan umpan balik dari hasil supervisi

\section{Metode dan Teknik Supervisi Pendidikan}

Metode supervisi pendidikan atau pengawasan adalah cara yang digunakan supervisior dalam menentukan tujuan pendidikan sedangkan Teknik supervisi pendidikan 
adalah langkah-langkah yang harus dilakukan untuk mencapai tujuan yang sudah ditentukan. Dalam supervisi penddidikan terdapat dua teknik besar yaitu teknik individual dan teknik kelompok sebagaimana yang dikemukakan oleh Direktorat Tenaga Pendidikan (Pendidikan, 2008) Teknik individual meliputi observasi, pertemuan individu, kunjungan antar guru, evaluasi diri, supervisi bulletin, bacaan profesional dan menulis profesional. Sedangkan Teknik Kelompok meliputi rapat sekolah, orientasi guru, laboratorium kurikulum, panitia, perpustakaan profesional, demonstrasi belajar, lokakarya, field trips for staff personnels, diskusi panel, in service training dan organisasi profesi.

Dengan adanya pendekatan supervisi, pemenuhan komponen yang berpengaruh pada supervisi, kompentensi yang harus dimiliki supervisior dan metode serta teknik supervisi pendidikan diharapkan dapat meningkatkan mutu pendidikan di Indonesia karena setiap supervisior bisa menjalankan tugasnya dan didukung oleh semua komponen yang terlibat dalam pendidikan.

\section{PENUTUP}

\section{Kesimpulan}

Berdasarkan pembahasan diatas disimpulkan bahwa Pendidikan di Indonesia diharapkan dapat menghasilkan peserta didik yang berprestasi akademik dan non akademik untuk meningkatkan mutu pendidikan di Indonesia sehingga dpat bersaing dalam kancah nasional sampai internasional. Keberhasilan supervisi pendidikan dapat diukur melalu peningkatan prestasi akademik dan non akademik. Supervisi pendidikan berperan dalam mengawasi kegiatan jalannya pendidikan, memperbaiki kekekurangan dan kesalahan dalam proses pendididikan, perencanaan, pengamatan, pembinaan dan pengawasan untuk meningkatkan mutu pendidikandi Indonesia.

\section{Saran}

Supervisi pendidikan sangat penting dan harus ada disetiap jenjang pendidikan yang dilaksanakan secara berkesinambungan agar dapat meningkatkan mutu pendidikan di Indonesia melalui peningkatan prestasi akademik dan non akademik peserta didik serta mencapai tujuan pendidikan nasional.

\section{REFERENSI}

Pendidikan, D. T. (2008). METODE DAN TEKNIK SUPERVISI. 1. Retrieved from http://file.upi.edu/Direktori/FIP/JUR._ADMINISTRASI_PENDIDIKAN/197205282005 011-NUR_AEDI/4-25/BAB_3_teknik_supervisi_[Nur_Aedi].pdf

Rahmat, S. (2015). SUPERVISI PENDIDIKAN GURU PROFESIONAL. 1. Retrieved from http://stitmatuban.ac.id/wp-content/uploads/2015/10/TD1.3-Supervisi-Pendidikan-H.Sutrisno-Rahmat.pdf

Sabandi,A.(2013). SUPERVISI PENDIDIKAN UNTUK PENGEMBANGAN PROFESIONALITAS GURU SUPERVISI PENDIDIKAN UNTUK PENGEMBANGAN PROFESIONALITAS GURU BERKELANJUTAN.Pedagogi, Jurnal Ilmiah Ilmu Pendidikan, XIII(No. 2),

1. Retrieved from http://ejournal.unp.ac.id/index.php/pedagogi/article/view/4275/3345

Suryana, S. (n.d.). PERMASALAHAN MUTU PENDIDIKAN DALAM PERPEKSTIF PEMBANGUNAN PENDIDIKAN.

1.Retrieved fromhttps://journal.unnes.ac.id/nju/index.php/edukasi/article/view/971/908

Suti, M. (2011). STRATEGI PENINGKATAN MUTU DI ERA OTONOMI PENDIDIKAN. Medtek,3.Retrievedfrom https://s3.amazonaws.com/academia.edu.documents/35942976/Jurnal_Pak_Marsus_Suti .pdf?AWSAccessKeyId=AKIAIWOWYYGZ2Y53UL3A\&Expires $=1 \overline{5} 55917336 \& \overline{\text { Signa }}$ ture $=\mathrm{Sg} 8 \mathrm{ZW} 9 \mathrm{vR} 1 \mathrm{xMbD} \% 2 \mathrm{BxnazI3kxiqAu} 8 \% 3 \mathrm{D} \&$ response-content disposition=inline\%3B filename\%3DJurnal_Pak_Marsus_Suti. 
